\title{
An Analysis of Key Ideas of Deconstruction through Franz Kafka's Metamorphosis
}

Amelia Price, University of Huddersfield amelia price1996@hotmail.co.uk Accepted date: 08/11/2017

Published date: 21/02/2018

\section{Abstract}

In On Truth and Lies in an Extra-Moral Sense, Friedrich Nietzsche challenged the correspondence theory of linguistic truth, suggesting that the inherently analogous nature of linguistic reason renders even the most foundational of truths to be illusory metaphors. Following in this distinctly anti-metaphysical strand of continental philosophy, Jacques Derrida formed a deconstructive method of reading where this Nietzschean approach to linguistic truth is imbued with a further ethico-political dimension. This entails undermining the ostensibly immutable and neutral character of metaphysical binaries inherent to our method of contradistinctive reason, instead presenting these binaries as rationally unstable hierarchies. This paper intends to apply such a method of reading to Franz Kafka's Metamorphosis, whereby methods of human reason are immediately undermined as the protagonist's unexplained and inexplicable metamorphosis into an insect occurs in the first sentence. Most prominently, this paper aims to discuss how Kafka deconstructs the metaphysical distinction between man and animal and the hierarchical relation implicit in this distinction. This distinction is particularly pertinent to Nietzschean scepticism towards linguistic reason, given both that our language remains a fundamentally human construct and the Aristotelian-scholastic notion of man as a 'rational animal'. 


\section{Keywords}

Nietzsche, Kafka, Derrida, post-structuralism, literature theory, deconstruction, binaries, logocentrism, metaphysics, anthropocentrism 
Post-structuralism is a radical departure from traditional humanist literary criticism that focuses on issues of morality and universal themes that seem implicit to the text itself. Deconstruction, as part of the post-structural movement, 'signifies a project of critical thought whose task is to locate and "take apart" those concepts which serve as ... axioms or rules' (Allison, 1973, p. xxxii). It examines language diachronically to gain understanding of the mechanisms of language as a system. The methodology is a 'systematic undoing of understanding' pioneered by philosopher Friedrich Nietzsche, who questioned the validity of objective truth in language (Syrotinski, 2007, p. 57). Nietzsche's theories regarding the dichotomy between truth and human experience made him a distinctly influential precursor to postmodern theory, with some critics crowning him 'the godfather of postmodernism' (Cahoone, 2003, p. 109). On Truth and Lies in an Extra-Moral Sense by Nietzsche (1954) was a fundamental text to deconstruction as a literary theory. Its influence can be seen through writers such as Kafka, who 'was a Nietzschean from way back, and he remains one throughout his work' (Sokel, 2011, p. 64). The post-structural impact of Nietzsche is apparent in Kafka's Metamorphosis through its disassembling of the assumed dualities in language, as well as the conspicuous absence of a coherent depiction of human and animal identity. Nietzsche's philosophy was also an antecedent to Jacques Derrida's work, as 'the contrast between truth and lie ... comes to be as a by-product of sociolinguistic institutions. Laws of truth emerge alongside linguistic legislations' (Cochran, 1998, p. 83). Building upon this, Derrida contends that within language there is not a 'peaceful coexistence of a vis-a-vis, but rather with a violent hierarchy. One of the two terms governs the other' (Derrida, 1982, p. 41). Derrida illustrates the problematic hierarchical nature of language as 'a structure - a system of oppositions of places and values', making claims that this 
structure inherently engenders privilege of one opposition above the other (Derrida, 1976, p. 166).

In On Truth and Lies in an Extra-Moral Sense, Nietzsche (1954) criticises the notion of empirical truth and substantiates that the notion of knowledge itself is a human fabrication. The purpose of this fabrication is to serve to manufacture an illusion of truth. The essay 'renders explicit the entangled political and epistemological ramifications of critical practice' (Cochran, 1998, p. 81). To Nietzsche, truth requires a logical heuristic method towards an absolute that is beyond humankind's limited cognitive ability. Thus, humankind's concept of truth is a fallacy comprising of 'metaphors which do not correspond to reality' (Glenn, 2004, p. 576). Knowledge 'has no further mission that would lead beyond human life', as humankind is the producer of this intellect that 'gives it such importance' (Nietzsche, 1954, p. 42). This is displayed in Metamorphosis, as once Gregor's anthropocentric position has been removed with his status as an insect - aligning himself with nature as opposed to man - there exists no motivation to conform to the metaphysical creation of knowledge, exhibiting 'how aimless and arbitrary, the human intellect appears in nature' (Nietzsche, 1954, p. 42). Nietzsche states that the falsification that is truth is an 'army of metaphors, metonyms, and anthropomorphisms' that can also be defined as 'a sum of human relations which have been enhanced' (Nietzsche, 1954, p. 4647). In applying this definition to Metamorphosis, when Gregor is no longer human, truth as a 'sum of human relations' becomes redundant and he speaks instead with 'no human voice' (Kafka, 1992, p. 19). Gregor's deviation from conventional truth is incomprehensible to the other characters: they repeatedly ask each other such questions as 'did you understand a single word?' whenever Gregor speaks (Kafka, 1992, p. 19). This incomprehension follows Nietzsche's claims that the purpose of 
truth serves to bolster human haughtiness. The value of knowledge stems from its own rhetoric; knowledge has '[carried] in itself the most flattering evaluation of knowledge' (Nietzsche, 1954, p. 43). Thus, when Gregor diverges from the illusion of truth that affirms knowledge's value and human importance, he disrupts the deception and renders humanity, and consequently, his family, insignificant. In doing so he is met with hostility and fear: 'Help, for God's sake, help!' (Kafka, 1992, p. 25). As communication breaks down when language is exposed to be a human construct with a finite, unstable existence, 'all linguistic signs are arbitrary' and 'meanings are maintained by convention only' (Peter, 2009, p. 62). Therefore, what Kafka implements in Metamorphosis and displays through Gregor is an anti-truth. It shows a deconstruction of language that reflects Nietzsche's post-structural influence on Kafka's writing.

Derrida, as the founding philosopher of deconstruction, was largely influenced by Ferdinand De Saussure's semiology to critique and analyse how meaning is derived from the articulation of rudimentary oppositions present within language. Saussure claims that 'in language there are only differences' that have produced a system of values that mean 'the idea or phonic substance that a sign contains is of less importance than the other signs that surround it' (Saussure, 1959, p. 121). His explanation that language gains meaning through reciprocal determination from within itself is the root of Derrida's deconstruction of language's binary oppositions, as he disapproved of Saussure's phonocentrism. Derrida demonstrates that these binaries create distinctions between words that are untenable, taking inspiration from Nietzsche's assertion that what is thought of as fundamental fact 'is precisely what there is not, only interpretations' (Nietzsche, 1967, p. 267). Within this theory, words garner meaning solely through their contrast with other words, which renders the 
word itself meaningless in isolation: 'one could reconsider all the pairs of opposites ... on which our discourse lives ... to see what indicates that each of the terms must appear as the différance of the other, as the other different and deferred in the economy of the same' (Derrida, 1992, p. 120). Consequently, meaning is deferred and is never explicitly present because it is defined by what surrounds it - 'no word can acquire meaning $\ldots$ by being the unmediated expression of something nonlinguistic' (Rorty, 1995, p. 173). Although predating Derrida, Kafka utilises the binary of human and animal within Metamorphosis to demonstrate a principle that bears striking resemblance to Derrida's critical theory. In such extracts as 'was he an animal, when music had such an effect on him?', Kafka creates contradictions between the distinction of this binary that associates animal with uncivilisation and favours human as superior and enlightened (Kafka, 1992, p. 53). The polarity is reversed as the text is instead favouring animal with the positive characteristics of human that allow Gregor to experience such typically human experiences as spiritual edification through music. Kafka's subversion of the hierarchical order within traditional language conventions that favour human over animal show not only that these concepts are defined in relation to each other, but that their differences are arbitrary. This demonstrates Derrida's principle that within language 'there are only contexts without any centre of absolute anchoring' (Derrida, 1977, p. 187). Kafka destabilises the established certainty in the structure of language, and shows that philological meaning is inextricable from one word to the next.

Saussure developed a set of rules for language (named 'Langue') that depicts language as a set of signs categorised into two groups that are arbitrarily bound together: the Signifier (written/sound construction that makes up the word) and the Signified (meaning of the word) (Saussure, 1983, p. 67). Deconstruction examines 
the ambiguities within signifiers and concludes that a single signifier possesses multiple varying signifieds. This shows the instabilities in their relationship to each other and seeks to challenge logocentric world views. In defiance of attempts to solidify language's meaning in the present moment of reality, Derrida states that différance 'expresses the interposition of delay, the interval of a spacing and temporalizing that puts off until "later" what is presently denied, the possible that is presently impossible' (Derrida, 1992, p. 111). This leads to gaps in relation to how language is used between experience and reality that depend on perspective. Kafka expresses this in Metamorphosis through an intermingling of different signifieds for a single signifier to show their lack of presence with reality. The signifier Gregor takes the shape of a bug, with Kafka making explicitly clear that this is the reality of the situation as the character has just awoken from 'uneasy dreams' (Kafka, 1992, p. 9). The signified of Gregor then becomes a bug, with a 'hard, as it were armour-plated, back' and 'numerous legs' (Kafka, 1992, p. 9). Yet the monologue of Gregor betrays this as it reveals a distinctly human thought process that is preoccupied with the struggles of everyday life: 'O God, he thought, what an exhausting job I've picked on!' (Kafka, 1992, p. 10). Thus, the signifier Gregor must equate to the signified human, and readers align to this view point, disregarding what Gregor actually indicates as a signifier. His family undergo the same illogical reasoning, but in reverse. To them, the signified of Gregor is a bug due to his inability to communicate his identity, despite knowing that in reality the signified is human. This is a momentary impossibility due to his appearance, so the signified becomes a monstrous burden: 'you must just try to get rid of the idea that this is Gregor' (Kafka, 1992, p. 56). The inclusion of multiple different signifieds creates a confusion that serves to deconstruct its meaning. This demonstrates that the meaning is dependent 
on the perspective of the person and their experience, rather than in correspondence with an objective reality. As such, for the Samsa family the signifier takes precedence over the signified. In reality, Gregor as a signifier has a multitude of signified meanings that are inextricable to each other, and therefore his existence lays somewhere in the ambiguities between them. This highlights the flaws in logocentrism of which Derrida, and deconstruction as a movement, remained critical.

In The Animal That Therefore I Am, Derrida deconstructs the philosophical conceptualisation of what is animal and what is human by exploring the limits of the interstitial space between them. He establishes his argument on the assertion that the entirety of the discourse, 'from Aristotle to Lacan, and including Descartes, Kant, Heidegger, and Levinas', states that 'the animal is without language' and humanity is distinguished by its ability to perceptualise reality into a concept (Derrida, 2002, p. 400). What inspired Derrida was Michel de Montaigne's umbrage with humankind's unfounded assumption that animals are without 'such portions of faculties' (Montaigne,1957, p. 331). Montaigne concludes that these naïve assumptions are seemingly unfounded: 'by what comparison between them and us does he infer the stupidity that he attributes to them?' (1957, p. 331). Derrida similarly builds upon Nietzsche's claims that humans use language as a sign of division because of anthropocentrism; humanity's belief 'in the concepts and names of things' allowed 'appropriat[ion] to himself that pride by which he raised himself above the animal' (Nietzsche,1986, p. 16). Thus, animals have been misinterpreted as 'unable to respond' due to their ontological difference and assumed subordination (Derrida, 2002, p. 400). Derrida challenges the hegemonic tradition that defines humankind through the devaluing of animals and focuses on humankind's inability to conclusively declare that animals are without the capacity to respond. Rather, he 
sees it that 'the animal is without the right and power to respond', as opposed to being unable to do so (Derrida, 2002, p. 400). In a continuation of this discourse, Metamorphosis problematises the supposed impossibility of language within animals and further illustrates the link between logocentrism and anthropocentrism. The father wishes that 'If only [Gregor] understood us', asserting that animals are beyond comprehension (Kafka, 1992, p. 55). Kafka undermines this by the father using 'a semi-questioning tone', exhibiting Derrida's dismantling of the postulation that animals are without the ability to use language (Kafka, 1992, p. 55). Gregor repeatedly shows he can comprehend through his acts of consideration, hiding himself from view to avoid shocking his family. Nevertheless, 'no request [of Gregor's] would even be understood', regardless of his actions, and 'his father just stomped all the harder' (Kafka, 1992, p. 11). Kafka suggests that rather than animals being unable to understand humanity, humankind is reluctant to - perhaps incapable of - understanding animality. The father's proposal that Gregor might be able to comprehend them, and thus share values that are typically attributed exclusively to humankind, is met with Grete's refusal of that possibility. The father 'absorb[s] the sister's conviction of the impossibility of this point', symbolising how the notion remains unchallenged within the philosophical field due to the automatic acceptance of orthodox views (Kafka, 1992, p. 56). Grete's assertion that the animal is not Gregor is accepted blindly due to humankind's hegemony over animals. Her narrative is recognised and valued, despite it being contrary to explicit evidence, because of the hierarchal relationship between humans and animals that wholly privileges humankind.

Derrida encourages an anti-human discourse to investigate the perceived boundaries between human and non-human in The Animal That Therefore I Am. 
Using Heidegger's delineation that 'a dog does not exist but merely lives', Derrida undermines the division between animality and humanity that is based on the ability to recognise and control one's own mortality (Heidegger,1995, p. 210). Derrida makes the distinction that what 'distinguishes [animal] from man, is ... not having knowledge of their nudity, in short without consciousness of good and evil' (Derrida, 2002 , p. 373). Animals are thus defined by their lack of recognition of morality and, as Nietzsche similarly concluded, 'without the errors which lie in the assumption of morality, man would have remained an animal' (Nietzsche,1986, p. 35). Metamorphosis anticipates this discussion due to how the text explores Gregor's identity after his physical anti-human metamorphosis. In a conspicuous reading, Gregor is ultimately a human trapped within an insect, since 'the language in which he thinks, cannot be readily ascribed to a bug' (Corngold \& Wagner, 2011, p. 64). However, Kafka abstractly presents human identity, as Gregor displays an amalgamation of typically humanistic and animalistic behaviours. Gregor struggles to identify wholly as insectile or human, and as the story progresses he acts more 'from animal instinct rather than self-conscious awareness' (Sweeney, 1990, p. 24). However, once he feels his humanity under attack with his family 'taking away from him everything he cherished' to facilitate his new insect body's needs, he concentrates his efforts on protecting a picture on the wall from being taken (Kafka,1992, p. 33). This is because to Gregor, that picture is a symbol of his human nature, and not allowing this to be confiscated is an act of preservation of his human identity. Even after refusing his animal identity, his animalistic impulses grow more pronounced and he lacks consciousness of his situation, exposing himself to the lodgers and putting his family in jeopardy. Yet this seems to have caused an epiphany, which can be read as the triumph of the human over the animal. Following 
this, Gregor suddenly no longer understands his insect body: 'it struck him as unnatural that he had really been able up to this point to move around with these thin little legs' (Kafka, 1992, p. 58). This leads to the sacrificial suicide of his animalistic self, meaning his family are no longer confronted with a complication of what constitutes a human that had disgusted them thus far. Gregor's ability to manipulate his existence and choose death despite being an animal defies not only Heidegger's definition of humanity as having exclusive control of their own mortality, but also Derrida's definition of humanity. Derrida states that humanity is established through its ownership of morality. However, Gregor, in spite of his position as an animal, shows a sensitivity to morality through his self-sacrifice, as this is the ethically righteous thing for him to do with his family in mind. Yet this is complicated by the fact that it is never made explicitly clear that Gregor's human conscience was his motivation to starve himself, despite starvation contradicting the motives of his animalistic nature. Kafka thus complicates the definition of human, rejecting the notions that Derrida and Heidegger suggest, without giving conclusive answers. Thus, his work proves both fruitful and divisive to the literary and philosophical discourse on what constitutes as humanity and the human condition.

\section{Conclusion}

When met with 'a secure axiom or a pithy maxim', the literary movement of deconstruction aims to 'crack it open and disturb this tranquillity' (Derrida \& Caputo, 2008, p. 32). Philosophers such as Nietzsche and Derrida have proved hugely influential in their rigorous interrogation of the diachronic aspect of logocentrism that has served to destabilise conventional certainties regarding truth, language and human identity. Nietzsche proposes a revisualisation of traditional systems of language as they possess no superior or inferior claim to validity in any noumenal 
sense. He believes that 'unchanging truths and stable ideas are falsifications' (Glenn, 2004, p. 576), implying that logocentrism has prevailed because 'all things that live long are gradually so saturated with reason that their origin in unreason thereby becomes improbable' (Nietzsche, 1997, p. 9). Derrida, in an attempt to move beyond Nietzsche's penultimate reassessment, wants to reach an ultimate understanding of how language formulates knowledge due its inherent stratified binaries. Derrida also explores how humankind has formulated its identity based on a false implicit inferiority of animals. Therefore, mirroring the system of language, humankind's conception of self is based on violent opposition with another. Some critics have claimed that Metamorphosis resists hermeneutics, making it difficult to conduct a deconstructive reading, because it 'is not an extended metaphor; it is the extension of a disintegrated metaphor - metaphor in a state of decay' (Corngold \& Wagner, 2011, p. 73). However, it is precisely its evasion of conventional metaphor and engagement with a self-nulling reference system that makes it an embodiment of deconstructive principles. Kafka challenges the binaries of animal and human in language, the legitimacy of objective truth and conceptualisation of human identity to 'validate contradictory readings that cancel coherent interpretation' (Ben-Ephraim, 1994, p. 451). Texts such as Metamorphosis can be used to test the strength of the deconstruction's thesis that Derrida, Nietzsche and the like wish to implore the literary field to implement going forward, while simultaneously reflecting the lasting impact that deconstruction has had in compromising the predominance of ostensibly fundamental notions. 


\section{References}

Allison, D. B. (1973). Introduction. In J. Derrida, Speech and Phenomena by Jacques Derrida. Evanston: Northwestern University Press.

Ben-Ephraim, G. (1994). Making and breaking meaning: Deconstruction, four-level allegory and the metamorphosis. Midwest Quarterly: A Journal of Contemporary Thought, 35(4), 450--467. Retrieved from http://library.hud.ac.uk/summon.

Cahoone, L. E. (2003). From mModernism to pPostmodernism: aAn aAnthology. New Jersey: Wiley-Blackwell.

Cochran, T. (1998). The Matter of Language. Boundary 2, 25(2), 71--93. doi:10.2307/303615.

Corngold, S., \& Wagner, B. (2011). Thirteen Ways of Looking at a Vermin. In Franz Kafka: The Ghosts in the Machine (pp. 57--73). Evanston: Northwestern University Press.

Derrida, J. \& Caputo, J. (2008). Deconstruction in a nutshell. New York: Fordham University Press.

Derrida, J. \& Spivak, G. C. (1976). Of Grammatology. (G.C. Spivak, Trans.). Baltimore: Johns Hopkins University Press.

Derrida, J. (1977). Margins of Philosophy. Chicago: University of Chicago Press.

Derrida, J., \& Bass, A. (1982). Positions. (A. Bass, Trans.). Chicago: University of Chicago Press. 
Derrida, J. (1992). Différance. In A.ntony Easthope and\& K.ate McGowan (Eds.), $A$ Critical and Cultural Theory Reader (pp.108--132). Buckingham: Open University Press.

Derrida, J., \& Wills, D. (2002). The Animal That Therefore I Am (More to Follow). (D. Wills, Trans.). Critical Inquiry, 28(2), 369--418. doi:10.1086/449046

Glenn, P. (2004). The Politics of Truth: Power in Nietzsche"s Epistemology. Political Research Quarterly, 57(4), 575--583. doi:10.2307/3219819.

Heidegger, M. (1995). The Fundamental Concepts of Metaphysics: World, Finitude, Solitude. Bloomington: Indiana University Press.

Kafka, F., Muir, W., \& Muir, E. (1992). Metamorphosis and other stories. (W. Muir \& E. Muir, Trans.). London: Minerva.

Montaigne, M. de D. (1957). Apology for Raymond Sebond. In D.onald M. Frame (Ed.), The Complete Works of Montaigne. California: Stanford University Press.

Nietzsche, F. (1954). 'On Truth and Lies in an Extra-Moral Sense'. In The Portable Nietzsche. (W. Kaufmann, Trans.). New York: Penguin Books.

Nietzsche, F. (1967). The Will Tto Power. (R. J. Hollingdale, \& W. Kaufmann, Trans.). New York: Random House.

Nietzsche, F. W. (1986). Human, aAll tToo hHuman: A bBook for fFree sSpirits. Cambridge: Cambridge University Press.

Nietzsche, F. W., Clark, M., Leiter, B., \& Hollingdale, R. J. (1997). Daybreak: Thoughts on the Prejudices of Morality (2nd ed.). M. Clark \& B. Leiter (Eds.). (R.J. Hollingdale, Trans.). Cambridge: Cambridge University Press. 
Peter, B. (2009). Beginning Theory: An Introduction to Literary and Cultural Theory. Manchester: Manchester University Press.

Rorty, R. (1995). Deconstructionist theory. In Ramen Selden (Ed.), The Cambridge History of Literary Criticism: Volume 8, From Formalism to Poststructuralism (pp. 166--196). Cambridge: Cambridge University Press.

Saussure, F. D. (1959). Course in General Linguistics. New York: New York Philosophical Library.

Saussure, F. D., Bally, C., Sechehaye, A., Riedlinger, A., \& Harris, R. (1983). Course in gGeneral ILinguistics. C. Bally, A. Sechehaye, \& A. Riedlinger (Eds.). (R. Harris, Trans.). London: Duckworth.

Sokel, W. H. (2011). Nietzsche and Kafka: The Dionysian Connection. In S. Corngold, S \& R.V. Gross, R. V (Eds.), Kafka For Tthe Twenty-First Century (pp. 64--74). Rochester: Camden House.

Sweeney, K. (1990). Competing Theories of Identity in Kafka"s '"The Metamorphosis'". Mosaic: A Journal for the Interdisciplinary Study of Literature, 23(4), 23--35. Retrieved from http://www.jstor.org.

Syrotinski, M. (2007). Deconstruction and the Postcolonial: At the Limits of Theory. Liverpool: Liverpool University Press. 